\title{
The environmental impact of remittance inflows in developing countries: Evidence from method of moments quantile regression
}

\section{Mahmoud Elbatanony}

Higher Future Institute for Specialized Technological Studies. Egypt

Imed Attiaoui ( $\Delta$ omda.attiaoui@gmail.com)

IHEC: Universite de Carthage Institut des Hautes Etudes Commerciales de Carthage

https://orcid.org/0000-0001-6606-6756

Ibrahim Mohamed Ali Ali

SAMS: Sadat Academy for Management Sciences

\section{Nahla Nasser}

Shaqra University

Monaem Tarchoun

Shaqra University

\section{Research Article}

Keywords: LMICs, CO2 emissions, EKC, Remittances, Method of moments quantile regression

Posted Date: March 1st, 2021

DOl: https://doi.org/10.21203/rs.3.rs-186596/v1

License: (c) (i) This work is licensed under a Creative Commons Attribution 4.0 International License.

Read Full License 


\title{
$\underline{\text { Title Page }}$
}

\section{The environmental impact of remittance inflows in developing countries: Evidence from method of moments quantile regression}

\author{
Mahmoud Elbatanony \\ ${ }^{a}$ Higher future institute for specialized technological studies. Egypt. \\ E-mail: dr_elbatanony@homail.com \\ Imed Attiaoui \\ ${ }^{b}$ College of business and administration. Shaqra University. Saudi Arabia \\ 'Institut des Hautes études commerciales de Carthage. Carthage University. Tunisia. \\ E-mail:omda.attiaoui@gmail.com \\ Ibrahim Mohamed Ali Ali \\ ${ }^{\mathrm{d} S a d a t}$ Academy for Management Sciences, SAMS. Egypt. \\ ${ }^{b}$ Faculty of Business. Shaqra University. Saudi Arabia \\ E-mail: ibrahimaliali2006@hotmail.com
}

\section{Nahla Nasser}

${ }^{e}$ College of science and human studies of Dawadmi. Shaqra University. Saudi Arabia.

E-mail: nassernehla@gmail.com

\section{Monaem Tarchoun}

${ }^{b}$ College of business and administration. Shaqra University. Saudi Arabia

E-mail: monaem tarchoun@yahoo.fr 


\title{
The environmental impact of remittance inflows in developing countries: Evidence from method of moments quantile regression
}

\begin{abstract}
Despite the importance of remittance inflows as potential source of incomes for recipient households and one of main contributors to the development process in various developing countries, their environmental effects have been largely neglected in empirical literature. To fill this gap, the current study proposes an extension of the conventional environmental Kuznets curve (EKC) by performing a modified version based on remittance inflows in both Low- and middle-income countries (LMICs) from 1980 to 2014. Using the novel method of moments quantile regression with fixed effect (MM-QR), the outcomes provide evidence of an inverted $\mathrm{N}$-Shaped EKC for remittances at higher $\mathrm{CO}_{2}$ emitters in lower-middle income countries (LMIC), proving that remittances allow recipient households to shift towards clean energy pattern (production/consumption). We find U-Shaped EKC for remittances from the $40^{\text {th }}$ to $80^{\text {th }}$ quantiles in upper middle-income countries (UMIC) along with monotonic negative effect on $\mathrm{CO}_{2}$ emissions at highest quantiles $\left(90^{\text {th }}\right.$ and $\left.95^{\text {th }}\right)$. No significant effect on environment has been outlined at lower $\mathrm{CO}_{2}$ emitters for all panels.

Regarding GDP per capita, an inverted N-Shaped EKC has been observed across all quantiles in UMIC and from lower to middle quantiles in Low-income countries (LIC). Finally, financial development (FD), as control variable, exerts significant mixed effect on $\mathrm{CO}_{2}$ emissions, swung between positive at all quantiles in LMIC and UMIC and negative at lower quantiles in LIC. Some recommendations were further built in the present study.
\end{abstract}

Keywords: LMICs; $\mathrm{CO}_{2}$ emissions; EKC; Remittances; Method of moments quantile regression. 


\section{Introduction}

Remittances inflows to the developing countries have been considered as one of the potential sources of funding, susceptive to achieving the Sustainable Development Goals (SDG) defined in the post-2015 Agenda of the United Nations Development Programme (UNDP).

The importance attributed to remittances comes from the surge of their value during recent decades, reaching a large share of GDP in many developing economies and that become an important source of income for the recipient households (Rahman et al., 2019; Goschin, 2014; Meyer and Shera, 2016). Remittance inflows to LMICs have grown rapidly (8.8\% in 2017 and $9.6 \%$ in 2018), to reach US\$529,640 million in 2018 up from US\$ 31,058 million in 1990 and expected to record $\$ 570$ billion in 2020 to become their largest source of foreign flows, often overtaking the value of foreign direct investments and official development aid (ODA) (World Bank (2018)).

Given their sheer magnitude and significance for the development process, remittance inflows have aroused a heightened interest of economists and policymakers. In this regard, the emphasis of studies has been focused mainly on the remittances-economic growth relationships (Benhamou and Cassan, 2020; Sobiech, 2019; Jouini, 2015; Senbeta, 2013;) as well as on their impacts on poverty and income inequality (Vacaflores, 2018; Apergis and Cooray, 2018; Wagle and Devkota, 2018; Bang et al., 2016). Furthermore, a vast literature has treated the effect of remittances on different components of human capital (health, education, labor productivity...) (Azizi, 2018; Pilarova and Kandakov, 2017; Bouoiyour and Miftah, 2016 ), while another strand of studies have highlighted the relationship between remittances and financial development (Opperman and Adjasi, 2019; Coulibaly, 2015; Brown et al., 2013).

However, despite the above aspects of remittances, the empirical evidences of their environmental consequences are, surprisingly, quite neglected and not still clear in the literature. Only three studies, to our best knowledge, have tried to investigate remittancesenvironment relationship (Khan et al. 2020; Rahman et al., 2019; Ahmad et al., 2019). Yet, there are several reasons to argue that remittances are likely to induce $\mathrm{CO}_{2}$ emissions through various ways: A direct effect could occur when remittances improve the standard of living of households, thereby generating higher levels of consumption (Thapa and Acharya, 2017; Amuedo and Pozo, 2004; Chami et al., 2005). More specifically, remittances could improve purchasing power, making it easier to acquire household items (automotive vehicles, air condition, computers, electric machines, etc.) and thus putting further pressure on energy consumption and $\mathrm{CO}_{2}$ emissions. Other direct effects may follow when the implementation of remittances-induced investment results in higher demand for energy. McKenzie and Sasin (2007) have underscored that remittances, as a transitory income, will be invested rather than spent. Remittances could swell the level of domestic investment by providing capital, supporting small firms and promoting real estate investment. This argument is in line with Shah (2017) who documented that about two-thirds of remittance in Nepal is allocated to the purchase of lands and houses.

At the same time, remittances could directly reduce $\mathrm{CO}_{2}$ emissions when a large portion of them is spent to cleaner energy use (e.g. solar energy,.) especially in case of high tariff and / or lack of electricity (Sharma et al., 2019). That is, the overall effect of remittances on environment depends on how it is implemented throughout the economy. 
On another side, remittances may indirectly affect the environment through several channels namely financial development and economic growth which are deemed to have a direct impact on $\mathrm{CO}_{2}$ emissions. Certainly, there is evidence to assume that remittances are highly correlated to these components. In this context, the literature tends to claim that remittances should stimulate macroeconomic variables by increasing aggregate demand, savings, investment and thus generating multiplier effects on economic growth which in turn affects the environment (Kadozi, 2019; Clemens and McKenzie, 2018; Ziesemer, 2012). In addition, remittances can be brought to bear for health and education spending along with enhancing labor productivity leading to support and improve economic growth (Mamun et al., 2015; Koska et al., 2013; Salas, 2014). Similarly, remittances contribute to financial development by providing complementary funding to the business community and relaxing the credit constraints as well as by increasing the demand for financial services (savings, transfer of money, etc,.) (Fromentin, 2017; Farhani and Ozturk, 2015). As a result, remittances as effective contributor to economic growth and financial development could affect indirectly $\mathrm{CO}_{2}$ emissions. In this context, various studies have investigated financial development- $\mathrm{CO}_{2}$ emissions links showing mixed effects (Boufateh and Saadaoui, 2020; Nassir et al. 2019; Charfeddine and kahia, 2019; Xing et al. 2017; Ayeche et al. 2016; Li and Ma, 2015). Nevertheless, it is argued that remittances may act as an alternative to financial development (Giuliano and Ruiz-Arranz, 2009; Nyamongo et al. 2012). It is assumed that if the banking sector is well developed, the investment credit constraints will therefore be limited and thereafter remittances will not be used necessarily for production and hence leading to less release of $\mathrm{CO}_{2}$. This substitutability could be conceived as the opposite effects of financial development facing those of remittances on $\mathrm{CO}_{2}$ emissions.

As for the effect of economic growth on $\mathrm{CO}_{2}$ emissions, the income per capita is widely considered as the most important variable related to environmental degradation. Thence, the most empirical literature has mainly been performed within the $(\mathrm{EKC})$ framework initiated by Grossman and Krueger (1995) (e.g. Boufatah, 2019; Sapkota and Bastola, 2017; Sarkodie and Strezov, 2019a). Accordingly, the EKC hypothesis exhibits an inverted U-shaped suggesting that income per capita initially leads to deterioration of environment, but after reaching a certain level, the quality of environment improves as income rises. Further, several studies suggest that environmental degradation will start to rise again beyond turning income level and thus the relationship turns to be N-shaped (Bhattarai et al. 2009; Alvares and Balsalobre 2016).

Proceeding from this concept, although remittances have then become an important additional source of income (outside-GDP) received directly by households, understanding their underlying effects on $\mathrm{CO}_{2}$ emissions remains an interesting question that is worth exploring. Thus, we propose to evaluate the EKC hypothesis for remittances (Rem) along with the conventional EKC in LMICs from 1980 to 2014. This study is focused on the underlying idea that remittances, as a specific income, might worsen environmental quality until reaching a turning point and improves it thereafter to rise again beyond a certain level. Hence, the main purpose of this study is to explore the possible N-shaped EKC and investigate whether remittances could affect $\mathrm{CO}_{2}$ emissions in developing countries. Moreover, we introduce financial development (FD) as a control variable to assess the possible substitutability effects on $\mathrm{CO}_{2}$ emissions with those of remittances. Further, considering remittances along with a 
control variable such as financial development is likely to avoid significant bias on income regressors.

To meet the outlined objectives, we conduct the study on a large array of countries divided into three heterogeneous panels based on the World Bank classification of income level (World Bank., 2020): lower-income countries (LIC), lower-middle-income countries (LMIC) and upper-middle-income countries (UMIC). The focus on these groups is justified by the noticeable ratios of remittance to their GDP and that around $70 \%$ of the international migrant come from these countries and hence enjoying from about three-quarters of international remittances transfers (Sobiech, 2019; Benhamou and Cassin, 2020). Further, breaking down middle-income countries in two sub-samples is to consider their diverse nature and their differentiated level of economic development. Another reason for selecting these countries is their heterogeneity not merely in terms of economic growth, but also in terms of remittances and $\mathrm{CO}_{2}$ emissions.

Therefore, we resort to the novel method of moments quantile regression with fixed effect (MM-QR) initiated by (Machado and Silva (2019)) to reveal whether the effects exerted by remittances alter across different quantiles of $\mathrm{CO}_{2}$ emissions inside each group. Using this approach allows us to find out a complete picture of the conditional distribution in comparison to OLS technique, especially in countries with low and high emissions.

This study distinguishes from the extant literature in three ways. First, such as the GDP per capita, this paper is the seminal empirical study investigating the effect of remittance on $\mathrm{CO}_{2}$ emissions through the EKC context. Second, even so a large body of literature has focused on the squared relationship to estimate the EKC; our study considers the cubic relationship to examine the possible N-shaped EKC. Third, to the best of our knowledge, our study is the first to employ the MM-QR to explore the heterogeneous effects as well of remittances as of the rest of the considered variables on $\mathrm{CO}_{2}$ emissions.

The remainder of the study is structured as follows. Section 2 presents the model specification. Section 3 describes the corresponding data and the panel quantile methodology. Section 4 proposes and discusses the empirical results. The conclusion and policy implications are presented in section 5 .

\section{Model specification}

As previously noted, no substantial attention has been paid to the impact of remittances on $\mathrm{CO}_{2}$ emissions. The purpose of our analysis is to test the $\mathrm{N}$-shaped EKC hypothesis based on the conventional income and, as novelty on remittances. In accordance with the EKC hypothesis (Grossman and Krueger (1995)), we perform the following model:

$$
\begin{aligned}
C O_{2 i t}=\alpha_{0 i}+ & \alpha_{1 i} G D P_{i t}+\alpha_{2 i} G D P_{i t}^{2}+\alpha_{3 i} G D P_{i t}^{3}+\beta_{1 i} R E M_{i t}+\beta_{2 i} R E M_{i t}^{2}+\beta_{3 i} R E M_{i t}^{3}+\omega_{i} F D_{i t} \\
& +\varepsilon_{i t}
\end{aligned}
$$

Where $\alpha_{0 i}$ refers to the country fixed effects. $\alpha_{1}, \alpha_{2}, \alpha_{3}, \beta_{1}, \beta_{2}$ and $\beta_{3}$, design the elasticities of carbon emissions with respect to economic growth (GDP) and remittances (Rem) along with their squared and cubic values respectively. $\omega$ measures the environmental pressure of financial development (FD). $\varepsilon_{\mathrm{it}}$ is the error term supposed to be independent and normally distributed. 
The EKC will adopt different shapes depending on both the significance and the expected signs of $\alpha_{1}\left(\beta_{1}\right), \alpha_{2}\left(\beta_{2}\right)$ and $\alpha_{3}\left(\beta_{3}\right)$ (Allard et al., 2018; Alvarez and Balsalobre, 2016):

- There is an N-shaped EKC when $\alpha_{1}\left(\beta_{1}\right)>0, \alpha_{2}\left(\beta_{2}\right)<0$ and $\alpha_{3}\left(\beta_{3}\right)>0$.

- An inverted $\mathrm{N}$-shaped EKC is depicted when $\alpha_{1}\left(\beta_{1}\right)<0, \alpha_{2}\left(\beta_{2}\right)>0$ and $\alpha_{3}\left(\beta_{3}\right)<0$.

- There is a classical $\mathrm{U}$ (inverted $\mathrm{U}$ )-shaped EKC if $\alpha_{3}\left(\beta_{3}\right)$ is not significant.

- There is a monotonic relationship between GDP (Rem) and $\mathrm{CO}_{2}$ emissions if only $\alpha_{1}\left(\beta_{1}\right)$ is significant.

The coefficient $\omega$ is expected to have different sign depending on whether financial development affects the environment.

\section{Data and Methodology}

\subsection{Method of moments quantile regression}

In this study, we employed panel quantile regression introduced by (Koenker and Bassett, 1978) to explore the impact of income per capita, remittances and financial development on $\mathrm{CO}_{2}$ emissions and to assess the $\mathrm{N}$-shaped Kuznets curve hypothesis. This method provides more understanding pictures of the influence of the independent variables by allowing regression's line slopes to differ across the quantiles of the dependent variable which is more powerful compared to the traditional regression techniques focus on the mean effects such as OLS. Moreover, this approach is more accurate in presence of outliers and if the random error term is not normally distributed (Zhu et al., 2018). Accordantly, using panel quantile regression makes it possible to investigate the $\mathrm{CO}_{2}$ emissions determinants via the conditional distribution across different panel.

However, quantile regression with individual effects suffers from some problems such as it does not take into account possible unobserved heterogeneity across individuals. Hence, we adopted the method of moments quantile regression with fixed effect recently introduced by Machado and Silva (2019). Based on conditional means, this method makes it possible to estimate the conditional quantiles through combined estimates of the location and scale functions. Indeed, The MM-QR permits the individual effects to influence both the location and scale of the dependent variable $\mathrm{Y}\left(\mathrm{CO}_{2}\right)$ and to impact the entire distribution instead of just shifting location such as in Koenker (2004) and Canay (2011). That is, this method provides information on how the conditional heterogeneous covariance effects of the determinants of $\mathrm{CO}_{2}$ emissions are identified. In addition, $\mathrm{MM}-\mathrm{QR}$ is very relevant when one's estimate quantile regression including individual effects and when the explanatory variables possess endogenous properties.

The MM-QR estimates the conditional quantiles of a dependent variable $\mathrm{Y}$ whose distribution conditional on a $\mathrm{k}$-vector of covariates $\mathrm{X}$ belongs to models of location-scale variant. $\mathrm{Y}$ is defined by the following form:

$$
Y_{i t}=\alpha_{i}+X_{i t}^{\prime} \beta+\left(\delta_{i}+Z_{i t}^{\prime} \gamma\right) U_{i t}
$$

where the probability, $P\left\{\delta_{i}+Z_{i t}^{\prime} \gamma>0\right\}=1 .\left(\alpha, \beta^{\prime}, \delta, \gamma^{\prime}\right)^{\prime}$ are unknown parameters to be estimated. 
$\left(\alpha_{i}, \delta_{i}\right), i=1, \ldots ., n$, represent the individual $i$ fixed effects, and $\mathrm{Z}$ includes k-vector of specified components of $\mathrm{X}$. These components are differentiable transformations with element $l$ given by:

$\mathrm{Z}_{l}=\mathrm{Z}_{l}(\mathrm{X}), l=1, \ldots . ., k$

$X_{i t}$ and $U_{i t}$ are i.i.d for any fixed $i$ and through time (t). According to (Machado and Silva 2019), $U_{i t}$ are orthogonal to $X_{i t}$ and standardized to satisfy the moment conditions which do not involve stringent exogeneity. Referring to Eq. (2), the conditional quantile $Q_{y}(\tau \mid x)$ of the dependent variable $\mathrm{Y}$ is expressed as follow:

$$
Q_{y}\left(\tau \mid X_{i t}\right)=\left(\alpha_{i}+\delta_{i} q(\tau)\right)+X_{i t}^{\prime} \beta+Z_{i t}^{\prime} \gamma q(\tau)
$$

where $X_{i t}^{\prime}$ includes the independent variables (GDP, GDP ${ }^{2}, \mathrm{GDP}^{3}, \mathrm{Rem}, \mathrm{Rem}^{2}, \mathrm{Rem}^{3}$ and FD). $Q_{y}\left(\tau \mid X_{i t}\right)$ denotes the quantile distribution of the dependent variable $Y_{i t}\left(\mathrm{CO}_{2}\right)$ which is conditional on the location of explanatory variables $X_{i t}$. The fixed effect of quantile $\tau$ for individual $i$ is defined by the scalar coefficient $\alpha_{\mathrm{i}}(\tau) ;\left(\alpha_{\mathrm{i}}(\tau) \equiv \alpha_{i}+\delta_{i} q(\tau)\right)$.

In Contrast to the standard least-square fixed effect, the individual effects do not evince intercept shift. As time-invariant parameters, their heterogeneous impacts are permissible to alter across the quantiles of the dependent variable Y. $q(\tau)$ is estimated from the following optimization problem:

$\operatorname{Min}_{q}=\sum_{i} \sum_{t} \rho_{\tau}\left(R_{i t}-\left(\delta_{i}+Z_{i t}^{\prime} \gamma\right) q\right)$

where $R_{i \mathrm{t}}=Y_{i t}-\left(\alpha_{i}+X_{i t}^{\prime} \beta\right)$ and $\quad \rho_{\tau}(A)=(\tau-1) A I\{A \leq 0\}+T A I\{\mathrm{~A}>0\}$ denotes the check function.

\subsection{Data}

We use a sample of 51 countries including three balanced panels presented in (Table.1): low income countries (LIC) (10), lower-middle-income countries (LMIC) (20) and upper-middleincome countries (UMIC) (21). As mentioned above, this classification stems from the World Bank (2020). We choose not to include high-income countries in the study since their remittance's contribution to the global share of GDP, is often minimal. The selection of countries in each panel is restricted by the availability of data especially related to remittances.

Table 1: Countries classification

\begin{tabular}{|c|c|c|}
\hline LIC & LMIC & UMIC \\
\hline $\begin{array}{l}\text { Benin; Burkina Faso, } \\
\text { Ethiopia; Madagascar; } \\
\text { Mali, Mozambique; } \\
\text { Niger; Rwanda; Sierra- } \\
\text { Leone; Togo. }\end{array}$ & $\begin{array}{l}\text { Bangladesh; Bolivia; Cabo Verde; } \\
\text { Cameroon, Congo. Rep; Cote } \\
\text { d'Ivoire; Egypt; El Salvador; } \\
\text { Eswatini; Ghana; Honduras; India; } \\
\text { Kenya; Nigeria; New Guinea; } \\
\text { Pakistan; Philippines; Senegal; } \\
\text { Sudan; Tunisia. }\end{array}$ & $\begin{array}{l}\text { Algeria; Argentina; Botswana, Brazil; } \\
\text { China; Colombia; Costa Rica; } \\
\text { Dominican. Rep; Fiji; Gabon; } \\
\text { Guatemala; Jamaica; Jordan; Malaysia; } \\
\text { Mexico; Paraguay; South Africa; Sri } \\
\text { Lanka; Suriname; Thailand; Turkey }\end{array}$ \\
\hline
\end{tabular}


For a deep understanding of the $\mathrm{N}$-shaped relationship, four variables are adopted in this study: $\mathrm{CO}_{2}$ emissions $\left(\mathrm{CO}_{2}\right)$ are used as indicator for environmental degradation; real GDP per capita (GDP) as proxy of economic growth and remittances per capita (Rem) are the annual amounts of remittances divided by the total population and financial development (FD) proxied by the domestic credit to private sector. Annual data cover a time horizon from 1980 to 2014 and were collected from the World Development Indicators (WDI). All variables are expressed in natural logarithms in order to overcome the potential heteroscedasticity problems and to make analysis more meaningful.

Table. 2 describes the different variables, while Table.3 reports the common sample descriptive statistics.

Table 2 : Variables definition

\begin{tabular}{|c|l|l|}
\hline Variable & \multicolumn{1}{|c|}{ Definition } & \multicolumn{1}{|c|}{ Source } \\
\hline $\mathbf{C O}_{2}$ & Carbon dioxide emissions (metric tons per capita) & World Development Indicators \\
\hline GDP & $\begin{array}{l}\text { Real gross domestic product per capita (constant } \\
\text { 2010 US\$) }\end{array}$ & World Development Indicators \\
\hline Rem & $\begin{array}{l}\text { Personal remittances per capita (received constant } \\
\text { 2010 US\$). Remittances are the sum of personal } \\
\text { current and compensation of employees. }\end{array}$ & World Development Indicators \\
\hline FD & Domestic credit to private sector (\% of GDP) & World Development Indicators \\
\hline
\end{tabular}

Table 3: Descriptive statistics for total sample

\begin{tabular}{|c|c|c|c|c|c|c|c|c|}
\hline Variable & Mean & Median & Maximum & Minimum & $\begin{array}{c}\text { Std. } \\
\text { Dev. }\end{array}$ & Skewness & Jarque-berra & N \\
\hline CO2 & -0.38 & -0.29 & 2.30 & -3.22 & 1.31 & -0.20 & $\begin{array}{c}61,03946 \\
(0.000)\end{array}$ & 1785 \\
\hline GDP & 7.49 & 7.53 & 9.49 & 4.89 & 1.04 & -0.19 & $\begin{array}{c}66,86485 \\
(0.000)\end{array}$ & 1785 \\
\hline REM & 2.58 & 2.75 & 6.67 & -5.38 & 2.08 & -0.57 & $\begin{array}{c}107,6759 \\
(0.000)\end{array}$ & 1785 \\
\hline FD & 3.06 & 3.05 & 5.11 & 0.43 & 0.78 & -0.17 & $\begin{array}{c}28,25745 \\
(0.000)\end{array}$ & 1785 \\
\hline
\end{tabular}

As reported in Table.3, Skewness values are negative and far from zero proving excessive skewness to the left for all variables. The Jarque-Bera statistical test strongly rejects the null hypothesis of normality confirming, once again, that applying OLS estimation will be inconsistent while employing quantile regression remains suitable and more robust for this study.

Table 4: Correlation matrix - Variance inflation factor

\begin{tabular}{|c|c|c|c|c|c|c|}
\hline & $\mathrm{CO}_{2}$ & GDP & Rem & FD & VIF & $1 /$ VIF \\
\hline $\mathrm{CO}_{2}$ & 1 & & & & - & - \\
\hline GDP & 0.87 & 1 & & & 1.271 & 0.787 \\
\hline Rem & 0.34 & 0.36 & 1 & & 1.266 & 0.791 \\
\hline FD & 0.55 & 0.4 & 0.39 & 1 & 1.31 & 0.763 \\
\hline Mean & - & - & - & - & 1.28 & - \\
\hline
\end{tabular}

Table.4 illustrates the correlation coefficients between the different variables as well as the variance inflation factor results. All correlation coefficients in absolute values between independent variables are less than 0.7. The results of the VIF test confirm the absence of 
multicollinearity between independent variables since the average value of 1.28 is less than 5 . The results of VIF support our view to consider GDP, Rem and FD in the same model.

\section{MM-QR results and discussion}

The estimate results obtained from MM-QR with fixed effect for different groups of countries are presented in Table 5, 6 and 7 respectively. For comparison, the graphics of the corresponding MM-QR and OLS estimators for each panel are provided by Fig.1, Fig.2 and Fig.

The panel quantile results are reported for 5th, 10th, ..., 90th and 95th percentiles of the conditional $\mathrm{CO}_{2}$ emissions in which the $5^{\text {th }}$ to $30^{\text {th }}$ percentile are used to examine the effect of GDP, Rem and FD in low $\mathrm{CO}_{2}$ emitters; from $40^{\text {th }}$ to $60^{\text {th }}$ percentile are adopted to specify the effects in medium $\mathrm{CO}_{2}$ emitters while from $70^{\text {th }}$ to $95^{\text {th }}$ percentiles are employed to explore the effects in high $\mathrm{CO}_{2}$ emitters.

The results from the method of moments quantile regressions showed heterogeneous effects across different quantiles and for different Panel-countries. The relationship between $\mathrm{CO}_{2}$ emissions and the explanatory variables is confirmed at some of quantiles and remains inconclusive at other ones. Hence, this finding deserves to be highlighted and explained with carefulness.

\subsection{Low-income countries (LIC)}

Regarding the estimation conducted for the first group of countries (LIC), presented in Table 5 , the coefficients related to GDP, GDP ${ }^{2}$ and $\mathrm{GDP}^{3}$ are significant and reveal homogeneously negative, positive and negative respectively along the $5^{\text {th }}-60^{\text {th }}$ quantiles and remain insignificant elsewhere. This result supports the validity of an inverted N-EKC for income in both low and medium $\mathrm{CO}_{2}$ emitters. This interesting finding could be explained by the economic nature of these countries as under-development economies where the high green technology is far from available to enhance the environment in first and/or in advanced development stage. Presumably, the pollution generated by the scale effects was compensated by other natural factors such as the expansion of forests in these regions or the adoption of cleaner practices related to the traditional agriculture susceptive to reduce $\mathrm{CO}_{2}$ emissions.

The effect of remittances (Rem) on $\mathrm{CO}_{2}$ emissions is negative but insignificant across all quantiles meaning that EKC-Rem is not supported for these countries. The insignificant effects of remittances on environmental pollution could be explained by the fact that, given the weakness of GDP per capita in such countries, remittances, as additional incomes, are entirely devoted to the consumption of basic necessities, health coverage and education, generating in turn fairly low levels of $\mathrm{CO}_{2}$ emissions. Rem ${ }^{2}$ reveals homogeneously positive, significant and gradually increased from $60^{\text {th }}$ to $95^{\text {th }}$ quantiles and remains insignificant for the rest ones. This means that reaching certain level, remittances could presumably be devoted to investment funding in polluting sectors inducing therefore environmental pollution in high $\mathrm{CO}_{2}$ emitter in particular.

The effect of financial development on $\mathrm{CO}_{2}$ emissions is negative, significant and decreases gradually (in absolute value) in low quantiles $\left(5^{\text {th }}-30^{\text {th }}\right)$. However, its effect becomes irrelevant when moving from the $40^{\text {th }}$ to $95^{\text {th }}$ quantiles reflecting an under development financial markets 
in such countries. The negative effect of (FD) on environment, found in this study, is confirmed by previous studies which point out that financial development reduces energy consumption and $\mathrm{CO}_{2}$ emissions by increasing energy efficient technologies (Pata, 2018; Shahzad et al., 2017). However, these studies were conducted on developed countries, suggesting that resorting to bank credits in low income-countries is essentially to meet certain consumption needs not emitter of $\mathrm{CO}_{2}$. Nevertheless, despite these mitigated effects, we can also observe that the impact of FD on $\mathrm{CO}_{2}$ emissions arises when the effect of remittances dissolves, reflecting a possible substitutability between the two components.

Table 5: MM-QR estimates for (LIC)

\begin{tabular}{|c|c|c|c|c|c|c|c|}
\hline & GDP & GDP $^{2}$ & $G P^{3}$ & Rem & $\operatorname{Rem}^{2}$ & $\operatorname{Rem}^{3}$ & FD \\
\hline Location & $\begin{array}{c}-29.930^{\star \star} \\
(0.048)\end{array}$ & $\begin{array}{l}4.4774^{*} \\
(0.095)\end{array}$ & $\begin{array}{c}-0.2115 \\
(0.183)\end{array}$ & $\begin{array}{c}-0.00234 \\
(0.939)\end{array}$ & $\begin{array}{c}0.01016 \\
(0.217)\end{array}$ & $\begin{array}{c}-0.000204 \\
(0.947)\end{array}$ & $\begin{array}{c}0.00246 \\
(0.959)\end{array}$ \\
\hline Scale & $\begin{array}{c}18.836 \text { ** } \\
(0.038)\end{array}$ & $\begin{array}{c}-3.5260^{* \star} \\
(0.029)\end{array}$ & $\begin{array}{c}0.21913^{\star *} \\
(0.022)\end{array}$ & $\begin{array}{c}0.00013 \\
(0.994)\end{array}$ & $\begin{array}{c}0.0137^{* * *} \\
(0.006)\end{array}$ & $\begin{array}{c}0.003386^{*} \\
(0.065)\end{array}$ & $\begin{array}{c}0.00244 \\
(0.932)\end{array}$ \\
\hline $5^{\text {th }}$ & $\begin{array}{c}-69.306^{\star * *} \\
(0.005)\end{array}$ & $\begin{array}{c}11.848^{* * *} \\
(0.007)\end{array}$ & $\begin{array}{c}-0.6696^{* *} \\
(0.01)\end{array}$ & $\begin{array}{c}-0.00263 \\
(0.959)\end{array}$ & $\begin{array}{c}-0.0186 \\
(0.165)\end{array}$ & $\begin{array}{c}-0.00728 \\
(0.144)\end{array}$ & $\begin{array}{c}-0.00265^{\star *} \\
(0.043)\end{array}$ \\
\hline $10^{\text {th }}$ & $\begin{array}{c}-60.407^{* * *} \\
(0.005)\end{array}$ & $\begin{array}{c}10.182^{\star *} \\
(0.008)\end{array}$ & $\begin{array}{c}-0.566^{* *} \\
(0.013)\end{array}$ & $\begin{array}{c}-0.00257 \\
(0.953)\end{array}$ & $\begin{array}{c}-0.01212 \\
(0.305)\end{array}$ & $\begin{array}{c}-0.00568 \\
(0.193)\end{array}$ & $\begin{array}{c}-0.00149^{*} \\
(0.063)\end{array}$ \\
\hline $20^{\text {th }}$ & $\begin{array}{c}-52.647^{* * *} \\
(0.006)\end{array}$ & $\begin{array}{c}8.73^{* *} \\
(0.011) \\
\end{array}$ & $\begin{array}{c}-0.475^{\star \star} \\
(0.019) \\
\end{array}$ & $\begin{array}{r}-0.0025 \\
(0.949) \\
\end{array}$ & $\begin{array}{c}-0.00645 \\
(0.541) \\
\end{array}$ & $\begin{array}{c}-0.003 \\
(0.3512) \\
\end{array}$ & $\begin{array}{c}-0.00089^{*} \\
(0.086)\end{array}$ \\
\hline $30^{\text {th }}$ & $\begin{array}{c}-42.504^{\star *} \\
(0.011)\end{array}$ & $\begin{array}{l}6.831^{* *} \\
(0.022)\end{array}$ & $\begin{array}{c}-0.3577^{* *} \\
(0.043)\end{array}$ & $\begin{array}{c}-0.0024 \\
(0.942)\end{array}$ & $\begin{array}{l}0.0059 \\
(0.917)\end{array}$ & $\begin{array}{c}-0.00246 \\
(0.466)\end{array}$ & $\begin{array}{c}-0.00072^{*} \\
(0.097)\end{array}$ \\
\hline $40^{\text {th }}$ & $\begin{array}{l}-34.14^{\star *} \\
(0.027)\end{array}$ & $\begin{array}{l}5.265^{\star *} \\
(0.055)\end{array}$ & $\begin{array}{l}-0.260^{*} \\
(0.058)\end{array}$ & $\begin{array}{c}-0.00237 \\
(0.939)\end{array}$ & $\begin{array}{c}0.00708 \\
(0.402)\end{array}$ & $\begin{array}{c}-0.00096 \\
(0.758)\end{array}$ & $\begin{array}{c}-0.00021 \\
(0.769)\end{array}$ \\
\hline $50^{\text {th }}$ & $\begin{array}{c}-28.619^{*} \\
(0.06)\end{array}$ & $\begin{array}{l}4.231^{*} \\
(0.071)\end{array}$ & $\begin{array}{l}-0.196^{*} \\
(0.069) \\
\end{array}$ & $\begin{array}{c}-0.00233 \\
(0.939)\end{array}$ & $\begin{array}{l}0.0111 \\
(0.182) \\
\end{array}$ & $\begin{array}{c}0.00003 \\
(0.992)\end{array}$ & $\begin{array}{c}0.00263 \\
(0.956)\end{array}$ \\
\hline $60^{\text {th }}$ & $\begin{array}{c}-22.307^{*} \\
(0.079) \\
\end{array}$ & $\begin{array}{l}3.0504^{*} \\
(0.092)\end{array}$ & $\begin{array}{l}-0.122^{*} \\
(0.095) \\
\end{array}$ & $\begin{array}{c}-0.00229 \\
(0.942)\end{array}$ & $\begin{array}{l}0.0157^{*} \\
(0.061)\end{array}$ & $\begin{array}{c}0.00116 \\
(0.707)\end{array}$ & $\begin{array}{l}0.00345 \\
(0.943)\end{array}$ \\
\hline $70^{\text {th }}$ & $\begin{array}{c}-16.738 \\
(0.297)\end{array}$ & $\begin{array}{c}2.008 \\
(0.481) \\
\end{array}$ & $\begin{array}{c}-0.058 \\
(0.731) \\
\end{array}$ & $\begin{array}{c}-0.00225 \\
(0.945)\end{array}$ & $\begin{array}{c}0.0198^{\star \star} \\
(0.024)\end{array}$ & $\begin{array}{c}0.00216 \\
(0.504)\end{array}$ & $\begin{array}{c}0.00417 \\
(0.935)\end{array}$ \\
\hline $80^{\text {th }}$ & $\begin{array}{c}-10.194 \\
(0.558) \\
\end{array}$ & $\begin{array}{l}0.782 \\
(0.8)\end{array}$ & $\begin{array}{l}0.0180 \\
(0.921) \\
\end{array}$ & $\begin{array}{r}-0.0022 \\
(0.951) \\
\end{array}$ & $\begin{array}{c}0.0245^{\star \star \star} \\
(0.010)\end{array}$ & $\begin{array}{c}0.00334 \\
(0.342) \\
\end{array}$ & $\begin{array}{l}0.0050 \\
(0.927) \\
\end{array}$ \\
\hline $90^{\text {th }}$ & $\begin{array}{l}-2.681 \\
(0.891) \\
\end{array}$ & $\begin{array}{c}-0.623 \\
(0.891) \\
\end{array}$ & $\begin{array}{c}0.105 \\
(0.616) \\
\end{array}$ & $\begin{array}{c}-0.00214 \\
(0.953)\end{array}$ & $\begin{array}{l}0.03^{\star * \star} \\
(0.006)\end{array}$ & $\begin{array}{l}0.0046 \\
(0.237)\end{array}$ & $\begin{array}{c}0.006 \\
(0.922)\end{array}$ \\
\hline $95^{\text {th }}$ & $\begin{array}{c}6.953 \\
(0.767) \\
\end{array}$ & $\begin{array}{c}-2.427 \\
(0.562) \\
\end{array}$ & $\begin{array}{c}0.217 \\
(0.382)\end{array}$ & $\begin{array}{c}-0.002077 \\
(0.964)\end{array}$ & $\begin{array}{c}0.03713^{\star * *} \\
(0.005)\end{array}$ & $\begin{array}{c}0.00642 \\
(0.174)\end{array}$ & $\begin{array}{c}0.007 \\
(0.920)\end{array}$ \\
\hline
\end{tabular}

Notes: ***,**, and * indicate significance at the 1,5 , and $10 \%$ levels, respectively. values in parentheses indicate the p-values.

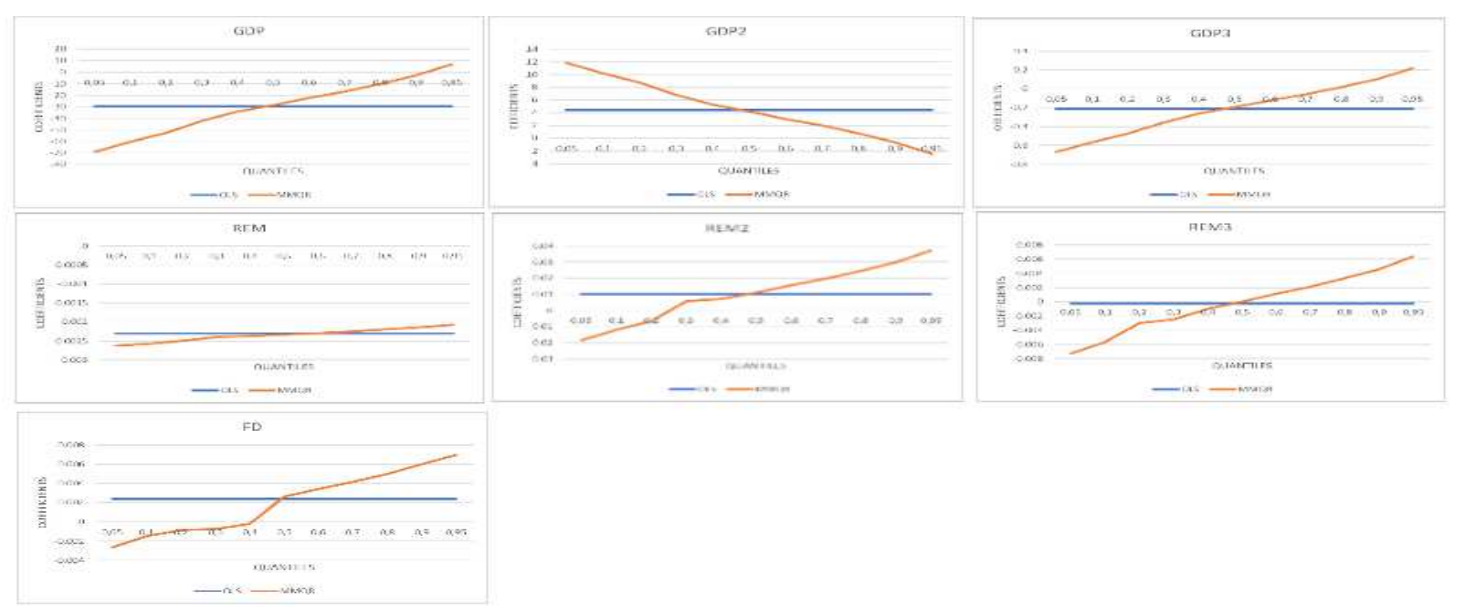

Fig1: Graphics of estimated coefficients from OLS and MMQR across all quantiles for all variables in LIC

The estimates also validate a U-shaped EKC from locational dimension. Indeed, the results showed that GDP per capita and its squared values $\left(\mathrm{GDP}^{2}\right)$ have effects with opposite signs on the location and scale assuming that increasing $\mathrm{GDP}\left(\mathrm{GDP}^{2}\right)$ reduces (increases) the average 
$\mathrm{CO}_{2}$ emissions, but also increases (reduces) the variance of $\mathrm{CO}_{2}$ across quantiles. However, $\mathrm{GDP}^{3}$ has no effect on location even if increases the dispersion of observed $\mathrm{CO}_{2}$ through all quantiles. Furthermore, despite their insignificant effects on the average $\mathrm{CO}_{2}$ emissions, $\mathrm{Rem}^{2}$ and $\mathrm{Rem}^{3}$ increase the scale of the observed dioxide-carbon emissions since the coefficients of $\mathrm{Rem}^{2}$ and $\mathrm{Rem}^{3}$ are significantly dispersed across quantiles as depicted by Fig.1.

\subsection{Lower middle-income countries (LMIC)}

Table 6 illustrates the outcomes of MM-QREG for (LMIC)). The empirical results deduced from MM-QR provide insignificant coefficients of GDP as well of their second and third polynomial excluding the existence of a relationship between environmental degradation and income. This result is very consistent with the study of (Allard et al., 2018) underscoring that, in lower middle-income countries, the $\mathrm{N}$-shaped Kuznets curve is depicted only in few quantiles. In line with these authors view, the disconnection between economic growth and $\mathrm{CO}_{2}$ release assumes that these countries have not yet achieved a desired level of income at the development stage allowing to intensify the production tools and to adopt technologies susceptive to influence the environment, whether in terms of pollution or in terms of mitigation. This disconnection could be also consistent with the idea that these economies are mainly focused on non-polluting sectors, namely traditional agricultural activities and light industries, which are far from using energy levels likely to release a large polluting amount of $\mathrm{CO}_{2}$.

Table 6: MM-QR estimates for (LMIC)

\begin{tabular}{|c|c|c|c|c|c|c|c|}
\hline & GDP & GDP $^{2}$ & $\mathrm{GDP}^{3}$ & Rem & $\operatorname{Rem}^{2}$ & $\operatorname{Rem}^{3}$ & FD \\
\hline Location & $\begin{array}{c}14.3759 \\
(0.227)\end{array}$ & $\begin{array}{l}-1.838 \\
(0.267)\end{array}$ & $\begin{array}{l}0.0811 \\
(0.290)\end{array}$ & $\begin{array}{l}-0.0235 \\
(0.404)\end{array}$ & $\begin{array}{l}0.0249 \\
(0.155)\end{array}$ & $\begin{array}{c}-0.0033 \\
(0.194)\end{array}$ & $\begin{array}{c}0.49477^{* * *} \\
(0.000)\end{array}$ \\
\hline Scale & $\begin{array}{c}5.91953 \\
(0.422)\end{array}$ & $\begin{array}{l}-0.883 \\
(0.39)\end{array}$ & $\begin{array}{c}0.043 \\
(0.365)\end{array}$ & $\begin{array}{c}-0.0328^{*} \\
(0.06)\end{array}$ & $\begin{array}{c}0.02067^{*} \\
(0.057)\end{array}$ & $\begin{array}{c}-0.00306^{*} \\
(0.056)\end{array}$ & $\begin{array}{c}0.07265^{\star * *} \\
(0.000)\end{array}$ \\
\hline 0.05 & $\begin{array}{c}2.160 \\
(0.911)\end{array}$ & $\begin{array}{c}-0.0139 \\
(0.996)\end{array}$ & $\begin{array}{c}-0.0077 \\
(0.95)\end{array}$ & $\begin{array}{l}0.0443 \\
(0.353)\end{array}$ & $\begin{array}{r}-0.0177 \\
(0.535)\end{array}$ & $\begin{array}{l}0.0029 \\
(0.481)\end{array}$ & $\begin{array}{c}0.3448^{* \star *} \\
(0.000)\end{array}$ \\
\hline 0.1 & $\begin{array}{l}5.048 \\
(0.76)\end{array}$ & $\begin{array}{l}-0.445 \\
(0.847)\end{array}$ & $\begin{array}{c}0.013 \\
(0.847)\end{array}$ & $\begin{array}{c}0.028 \\
(0.471)\end{array}$ & $\begin{array}{c}-0.0076 \\
(0.753)\end{array}$ & $\begin{array}{l}0.0014 \\
(0.681)\end{array}$ & $\begin{array}{c}0.380^{* * *} \\
(0.000)\end{array}$ \\
\hline 0.2 & $\begin{array}{l}8.281 \\
(0.556)\end{array}$ & $\begin{array}{l}-0.928 \\
(0.636)\end{array}$ & $\begin{array}{c}0.036 \\
(0.685)\end{array}$ & $\begin{array}{c}0.0103 \\
(0.0 .757)\end{array}$ & $\begin{array}{l}0.0036 \\
(0.861)\end{array}$ & $\begin{array}{l}-0.0001 \\
(0.948)\end{array}$ & $\begin{array}{c}0.419^{* * *} \\
(0.000)\end{array}$ \\
\hline 0.3 & $\begin{array}{l}10.465 \\
(0.414)\end{array}$ & $\begin{array}{l}-1.254 \\
(0.483)\end{array}$ & $\begin{array}{l}0.0526 \\
(0.524)\end{array}$ & $\begin{array}{l}-0.0017 \\
(0.953)\end{array}$ & $\begin{array}{l}0.0112 \\
(0.551)\end{array}$ & $\begin{array}{c}-0.0013 \\
(0.632)\end{array}$ & $\begin{array}{c}0.446^{* * *} \\
(0.000)\end{array}$ \\
\hline 0.4 & $\begin{array}{l}12.273 \\
(0.313)\end{array}$ & $\begin{array}{l}-1.524 \\
(0.368)\end{array}$ & $\begin{array}{l}0.0658 \\
(0.401)\end{array}$ & $\begin{array}{l}-0.011 \\
(0.681)\end{array}$ & $\begin{array}{l}0.0175 \\
(0.325)\end{array}$ & $\begin{array}{c}-0.0022 \\
(0.39)\end{array}$ & $\begin{array}{c}0.468^{* \star \star} \\
(0.000)\end{array}$ \\
\hline 0.5 & $\begin{array}{l}14.093 \\
(0.236)\end{array}$ & $\begin{array}{l}-1.795 \\
(0.279)\end{array}$ & $\begin{array}{c}0.079 \\
(0.303)\end{array}$ & $\begin{array}{l}-0.021 \\
(0.437)\end{array}$ & $\begin{array}{c}0.023 \\
(0.172)\end{array}$ & $\begin{array}{c}-0.003 \\
(0.214)\end{array}$ & $\begin{array}{c}0.491^{* * *} \\
(0.000)\end{array}$ \\
\hline 0.6 & $\begin{array}{l}15.828 \\
(0.189)\end{array}$ & $\begin{array}{l}-2.054 \\
(0.221)\end{array}$ & $\begin{array}{l}0.0917 \\
(0.238)\end{array}$ & $\begin{array}{c}-0.0315 \\
(0.27)\end{array}$ & $\begin{array}{c}0.03 \\
(0.102)\end{array}$ & $\begin{array}{c}-0.0041 \\
(0.117)\end{array}$ & $\begin{array}{c}0.512^{* * \star} \\
(0.000)\end{array}$ \\
\hline 0.7 & $\begin{array}{l}18.196 \\
(0.157)\end{array}$ & $\begin{array}{l}-2.408 \\
(0.179)\end{array}$ & $\begin{array}{c}0.108 \\
(0.189)\end{array}$ & $\begin{array}{l}-0.044^{*} \\
(0.092)\end{array}$ & $\begin{array}{l}0.0382^{*} \\
(0.054)\end{array}$ & $\begin{array}{c}-0.0053^{*} \\
(0.057)\end{array}$ & $\begin{array}{c}0.541^{* * *} \\
(0.000)\end{array}$ \\
\hline 0.8 & $\begin{array}{l}20.844 \\
(0.148)\end{array}$ & $\begin{array}{l}-2.804 \\
(0.163)\end{array}$ & $\begin{array}{c}0.128 \\
(0.168)\end{array}$ & $\begin{array}{l}-0.059^{*} \\
(0.083)\end{array}$ & $\begin{array}{c}0.0475^{\star \star} \\
(0.026)\end{array}$ & $\begin{array}{c}-0.0066^{* *} \\
(0.033)\end{array}$ & $\begin{array}{c}0.574^{\star \star *} \\
(0.000)\end{array}$ \\
\hline 0.9 & $\begin{array}{l}23.969 \\
(0.157)\end{array}$ & $\begin{array}{c}-3.27 \\
(0.166)\end{array}$ & $\begin{array}{c}0.15 \\
(0.167)\end{array}$ & $\begin{array}{c}-0.0768^{*} \\
(0.056)\end{array}$ & $\begin{array}{c}0.0584^{\star *} \\
(0.019)\end{array}$ & $\begin{array}{c}-0.0083^{\star *} \\
(0.024)\end{array}$ & $\begin{array}{c}0.612^{* * *} \\
(0.000)\end{array}$ \\
\hline 0.95 & $\begin{array}{l}26.119 \\
(0.168)\end{array}$ & $\begin{array}{l}-3.591 \\
(0.173)\end{array}$ & $\begin{array}{c}0.166 \\
(0.172)\end{array}$ & $\begin{array}{c}-0.0887^{* *} \\
(0.048)\end{array}$ & $\begin{array}{l}0.065^{* *} \\
(0.018)\end{array}$ & $\begin{array}{c}-0.0094^{* *} \\
(0.022)\end{array}$ & $\begin{array}{c}0.638^{* * *} \\
(0.000)\end{array}$ \\
\hline
\end{tabular}

The MM-QR estimates show that the effects of remittances on $\mathrm{CO}_{2}$ emissions are insignificant at low and middle quantiles $\left(5^{\text {th }}-60^{\text {th }}\right)$, while their effects become negative and statistically significant from higher quantiles $\left(70^{\text {th }}, 80^{\text {th }} 90^{\text {th }}, 95^{\text {th }}\right)$. When moving from the 70 th to 95 th 
quantile, we can notice a gradual dwindling of $\mathrm{CO}_{2}$ emissions and that the effect of remittances becomes more significant inferring that remittances are inclined to the adoption of cleaner technologies. The negative effect of remittances on carbon-dioxide has been found by Khan et al. (2020) in India assuming that received remittances lead to enhance the environmental quality. Similarly, at higher quantiles, the relationship between $\mathrm{Rem}^{2}$ and $\mathrm{CO}_{2}$ emissions are homogeneously positive and significant, whereas $\mathrm{CO}_{2}$ emissions decreases with increasing $\mathrm{Rem}^{3}$. That is, the MM-QR estimates corroborate the validity of an inverted N-shaped Kuznets curve for remittances in higher quantiles. Even it is difficult to explain this interesting finding, remittances are probably spent, at initial stages, for the use of cleaner energy in order to overcome the lack of electricity for lighting, hydraulic pumping, etc., or for clean agricultural activities such as trees-cropping likely to reduce $\mathrm{CO}_{2}$ release. Thereafter, recording high level, along with the weakness of incomes, remittances would be oriented towards polluting production inducing hence environmental degradation. Further, reaching large higher values, remittances would possibly invest in eco-friendly technology which in turn leads to less energy consumption and $\mathrm{CO}_{2}$ emissions. Accordantly, when reaching higher level, remittances allow recipient households to shift towards clean energy pattern in terms of production or consumption.

In other ways, a strong significant effect of $\mathrm{FD}$ on $\mathrm{CO}_{2}$ emissions is observed when using MM-QR. A positive association exists between financial development and $\mathrm{CO}_{2}$ emissions across all quantiles at $1 \%$ significance level suggesting that the banking sector, in these countries, remains the most important source of investment-funding and that the banking credits contribute a priori to the financing of economic projects emitters of $\mathrm{CO}_{2}$. It is noteworthy to point out that starting from lower towards higher quantiles, the effect of $\mathrm{FD}$ on $\mathrm{CO}_{2}$ is increasingly upsurging. Indeed, the increase in $\mathrm{FD}$ by $1 \%$ rises $\mathrm{CO}_{2}$ emissions by $0.344-0.638 \%$ implying that more financial development leads to more environmental degradation.

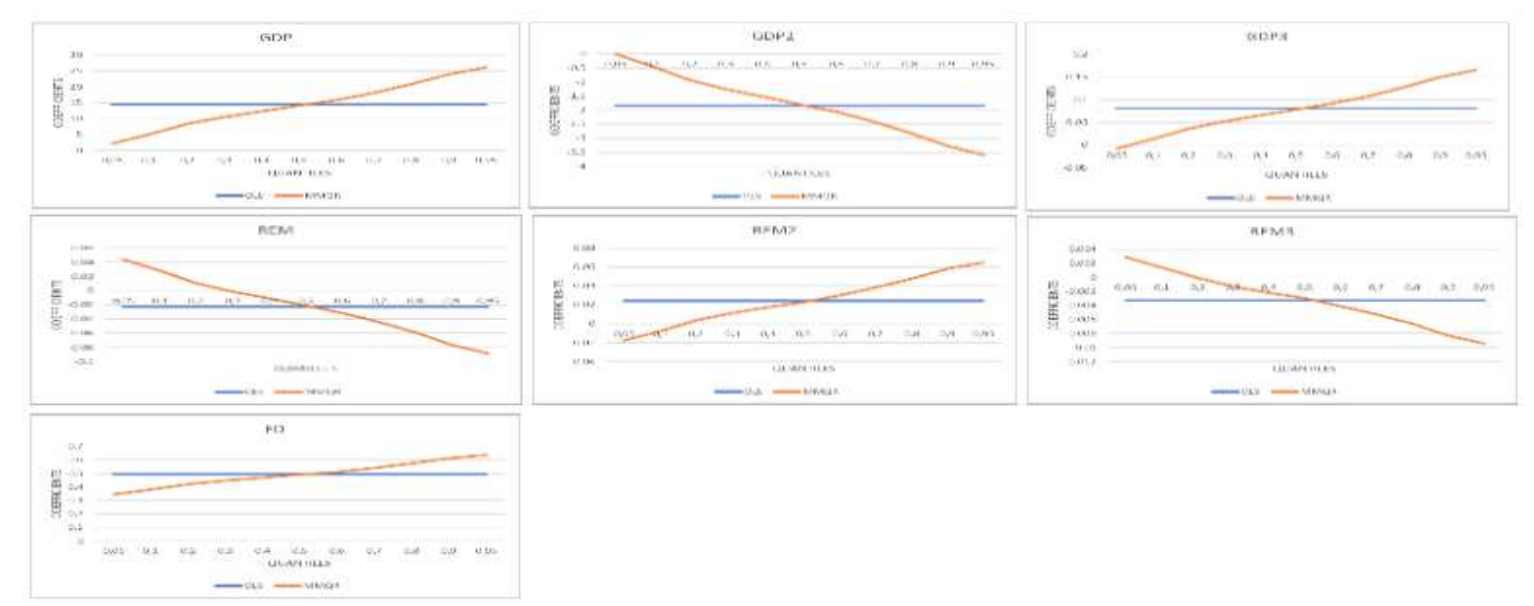

Fig 2: Graphics of estimated coefficients from OLS and MMQR across all quantiles for all variables in LMIC

For location and scale parameters estimates, while the N-shaped EKC for remittances is not validated from locational dimension, the effects of Rem, $\mathrm{Rem}^{2}$ and $\mathrm{Rem}^{3}$ have an increase variance across quantiles as showed in Fig. 2. Financial development not only significantly affects the average $\mathrm{CO}_{2}$ emissions from the locational dimension but also increases the dispersion of observed $\mathrm{CO}_{2}$ across quantiles. 


\section{3. Upper middle-income countries (UMIC)}

The MM-QR results showed evidence from an inverted N-shaped EKC for GDP in (UMIC) at all quantiles. Indeed, as seen in Table 7, the coefficients related to GDP and their quadratic and cubic values are significant and reveal homogeneously negative, positive and negative respectively along all quantiles. The decline of $\mathrm{CO}_{2}$ could be due to technological transfer and may be a compensation effect generated by high-energy efficiency against the scale effectinduced pollution, which further leading to a negative effect of GDP on $\mathrm{CO}_{2}$ emanation (Sarkodie and Strezof, 2019b; Allard et al., 2018).

Table 7: MM-QR estimates for (UMIC)

\begin{tabular}{|c|c|c|c|c|c|c|c|}
\hline Quantile & GDP & GDP $^{2}$ & $G P^{3}$ & Rem & Rem $^{2}$ & $\operatorname{Rem}^{3}$ & FD \\
\hline Location & $\begin{array}{c}-39.453^{\star * *} \\
(0.000) \\
\end{array}$ & $\begin{array}{c}5.0132^{\star \star \star} \\
(0.000)\end{array}$ & $\begin{array}{c}-0.206^{\star \star \star} \\
(0.000)\end{array}$ & $\begin{array}{c}-0.088^{\star *} \\
(0.022) \\
\end{array}$ & $\begin{array}{c}-0.0375^{\star \star} \\
(0.038)\end{array}$ & $\begin{array}{c}0.0073^{\star \star *} \\
(0.001)\end{array}$ & $\begin{array}{c}0.312^{\star \star \star} \\
(0.000)\end{array}$ \\
\hline Scale & $\begin{array}{l}-1.699 \\
(0.642) \\
\end{array}$ & $\begin{array}{c}0.304 \\
(0.515) \\
\end{array}$ & $\begin{array}{c}-0.016 \\
(0.409) \\
\end{array}$ & $\begin{array}{c}-0.065^{\star * \star} \\
(0.003)\end{array}$ & $\begin{array}{c}0.006 \\
(0.561) \\
\end{array}$ & $\begin{array}{c}0.00009 \\
(0.940)\end{array}$ & $\begin{array}{c}0.014 \\
(0.378) \\
\end{array}$ \\
\hline 0.05 & $\begin{array}{c}-35.939^{* * *} \\
(0.002)\end{array}$ & $\begin{array}{c}4.383^{\star \star \star} \\
(0.003)\end{array}$ & $\begin{array}{c}-0.172^{\star \star *} \\
(0.006)\end{array}$ & $\begin{array}{l}0.0477 \\
(0.495)\end{array}$ & $\begin{array}{c}-0.0499 \\
(0.128)\end{array}$ & $\begin{array}{c}0.00711^{*} \\
(0.086)\end{array}$ & $\begin{array}{l}0.282^{\star * *} \\
(0.000)\end{array}$ \\
\hline 0.1 & $\begin{array}{c}-36.462^{\star * *} \\
(0.001)\end{array}$ & $\begin{array}{c}4.477^{* * *} \\
(0.001)\end{array}$ & $\begin{array}{c}-0.177^{\star * *} \\
(0.002)\end{array}$ & $\begin{array}{c}0.027 \\
(0.669)\end{array}$ & $\begin{array}{r}-0.0481 \\
(0.110) \\
\end{array}$ & $\begin{array}{c}0.00714^{*} \\
(0.060)\end{array}$ & $\begin{array}{c}0.2866^{\star * *} \\
(0.000)\end{array}$ \\
\hline 0.2 & $\begin{array}{c}-37.344^{* * *} \\
(0.000) \\
\end{array}$ & $\begin{array}{c}4.635^{\star * *} \\
(0.000)\end{array}$ & $\begin{array}{c}-0.186^{* * *} \\
(0.000)\end{array}$ & $\begin{array}{c}-0.00678 \\
(0.903)\end{array}$ & $\begin{array}{l}-0.045^{*} \\
(0.082) \\
\end{array}$ & $\begin{array}{c}0.00719^{* *} \\
(0.027)\end{array}$ & $\begin{array}{c}0.294^{\star * *} \\
(0.000)\end{array}$ \\
\hline 0.3 & $\begin{array}{c}-38.309^{* * *} \\
(0.001)\end{array}$ & $\begin{array}{c}4.808^{\star * *} \\
(0.000)\end{array}$ & $\begin{array}{c}-0.195^{\star * *} \\
(0.000)\end{array}$ & $\begin{array}{c}-0.044 \\
(0.346)\end{array}$ & $\begin{array}{c}-0.0415^{*} \\
(0.055)\end{array}$ & $\begin{array}{c}0.0072^{\star * *} \\
(0.008)\end{array}$ & $\begin{array}{c}0.302^{* * *} \\
(0.000)\end{array}$ \\
\hline 0.4 & $\begin{array}{c}-39.171^{* * *} \\
(0.000)\end{array}$ & $\begin{array}{c}4.962^{* * *} \\
(0.000)\end{array}$ & $\begin{array}{c}-0.203^{* * *} \\
(0.000)\end{array}$ & $\begin{array}{c}-0.0777^{*} \\
(0.055)\end{array}$ & $\begin{array}{c}-0.0385^{\star *} \\
(0.041)\end{array}$ & $\begin{array}{c}0.0072^{\star * *} \\
(0.002)\end{array}$ & $\begin{array}{c}0.310^{* * *} \\
(0.000)\end{array}$ \\
\hline 0.5 & $\begin{array}{c}-39.751^{\star * *} \\
(0.000)\end{array}$ & $\begin{array}{c}5.066^{\star * *} \\
(0.000)\end{array}$ & $\begin{array}{c}-0.209^{\star * *} \\
(0.000)\end{array}$ & $\begin{array}{c}-0.100^{\star * *} \\
(0.008)\end{array}$ & $\begin{array}{c}-0.036^{\star *} \\
(0.037)\end{array}$ & $\begin{array}{c}0.0073^{\star * *} \\
(0.001)\end{array}$ & $\begin{array}{c}0.315^{\star * *} \\
(0.000)\end{array}$ \\
\hline 0.6 & $\begin{array}{c}-40.321^{\star \star *} \\
(0.000)\end{array}$ & $\begin{array}{c}5.168^{\star * \star} \\
(0.000)\end{array}$ & $\begin{array}{c}-0.214^{* * *} \\
(0.000)\end{array}$ & $\begin{array}{c}-0.122^{\star * *} \\
(0.001)\end{array}$ & $\begin{array}{c}-0.034^{\star *} \\
(0.041)\end{array}$ & $\begin{array}{c}0.0073^{\star \star *} \\
(0.001)\end{array}$ & $\begin{array}{c}0.320^{* * *} \\
(0.000)\end{array}$ \\
\hline 0.7 & $\begin{array}{c}-40.808^{\star \star \star} \\
(0.000)\end{array}$ & $\begin{array}{c}5.256^{\star \star \star} \\
(0.000)\end{array}$ & $\begin{array}{c}-0.219^{\star * *} \\
(0.000)\end{array}$ & $\begin{array}{c}-0.141^{\star \star *} \\
(0.000)\end{array}$ & $\begin{array}{l}-0.032^{*} \\
(0.052)\end{array}$ & $\begin{array}{c}0.0073^{\star \star \star} \\
(0.001)\end{array}$ & $\begin{array}{c}0.324^{\star * *} \\
(0.000)\end{array}$ \\
\hline 0.8 & $\begin{array}{c}-41.351^{* * *} \\
(0.001)\end{array}$ & $\begin{array}{l}5.353^{* * *} \\
(0.0012)\end{array}$ & $\begin{array}{c}-0.224^{* * *} \\
(0.000)\end{array}$ & $\begin{array}{c}-0.162^{\star \star *} \\
(0.000)\end{array}$ & $\begin{array}{c}-0.03^{*} \\
(0.078)\end{array}$ & $\begin{array}{c}0.0074^{\star * *} \\
(0.001)\end{array}$ & $\begin{array}{c}0.329^{* * *} \\
(0.000)\end{array}$ \\
\hline 0.9 & $\begin{array}{c}-41.721^{* * *} \\
(0.000)\end{array}$ & $\begin{array}{c}5.419^{* \star *} \\
(0.000)\end{array}$ & $\begin{array}{c}-0.228^{* \star *} \\
(0.000)\end{array}$ & $\begin{array}{c}-0.176^{\star * *} \\
(0.000)\end{array}$ & $\begin{array}{l}-0.029 \\
(0.105)\end{array}$ & $\begin{array}{c}0.00744^{* * *} \\
(0.001)\end{array}$ & $\begin{array}{c}0.332^{\star * *} \\
(0.000)\end{array}$ \\
\hline 0.95 & $\begin{array}{c}-41.984^{\star * *} \\
(0.000)\end{array}$ & $\begin{array}{c}5.466^{\star * *} \\
(0.000)\end{array}$ & $\begin{array}{r}-0.23^{\star * *} \\
(0.000)\end{array}$ & $\begin{array}{c}-0.186^{\star * *} \\
(0.000)\end{array}$ & $\begin{array}{l}-0.028 \\
(0.131)\end{array}$ & $\begin{array}{c}0.0074^{\star \star *} \\
(0.002)\end{array}$ & $\begin{array}{c}0.335^{\star * *} \\
(0.000)\end{array}$ \\
\hline
\end{tabular}

From the middle $\left(40^{\text {th }}\right)$ to higher quantiles $\left(95^{\text {th }}\right)$, remittances generate a strong gradual negative effect on $\mathrm{CO}_{2}$ emissions with $1 \%$ level of significance. Similar to the low-income countries, the effect of remittances remains insignificant at lower quantiles. Remittances squared cause a negative effect from the $20^{\text {th }}$ to the $80^{\text {th }}$ quantiles, showing inconclusive aggregated weight on $\mathrm{CO}_{2}$ emissions. In addition, the effect of $\mathrm{Rem}^{3}$ on $\mathrm{CO}_{2}$ emissions is positively significant across all quantiles providing evidence that reaching higher values, remittances would cause a rise in $\mathrm{CO}_{2}$ emanation. This statement has been validated by Khan et al. (2020) suggesting that, in the long-term, remittances escalate the $\mathrm{CO}_{2}$ emissions in some BRICS countries which are part of Upper middle-income countries. Nevertheless, the signs of Rem, Rem ${ }^{2}$ and Rem ${ }^{3}$ support the validity of a U-Shaped EKC at the $40^{\text {th }}$ to $80^{\text {th }}$ quantiles. Moreover, at the highest quantiles $\left(90^{\text {th }}\right.$ and $\left.95^{\text {th }}\right)$, the insignificant effect of $\mathrm{Rem}^{2}$ indicates that the relationship between remittances and $\mathrm{CO}_{2}$ emissions is negatively monotonic excluding the validity of the EKC hypothesis. 
Such as in LMIC, financial development increases $\mathrm{CO}_{2}$ emissions across all quantiles at $1 \%$ significance level. FD gradually increases $\mathrm{CO}_{2}$ emissions from the lower to the higher quantiles meaning that FD- environment degradation relationship is highly quantile dependent.

The positive connection between FD and environment has been outlined by previous studies such as (Kayani et al., 2020; Wang et al., 2019; Bekhet and Othman, 2017; Ito, 2017 ; Jebli et al., 2016; Gunasekaran et al., 2014) which have pointed out that, in case of developed financial markets, the investors can get credits at low rates allowing purchasing machinery increasing thus the release of dioxide-carbon. Further, higher is the financial development, more are foreign investors attracted and then contributing to the environmental degradation.

However, it should be noted that in low quantiles, the effect of FD surges when the effect of remittances is inconclusive, but starting from the middle to higher quantiles, this effect is in part compensated by the negative effect of remittances when credits banking seems to become more expensive.

According to the location and scale estimates, the results showed that all explanatory variables strongly affect the average $\mathrm{CO}_{2}$ emissions and that only remittances coefficient has higher negative dispersion of $\mathrm{CO}_{2}$ across quantiles as presented in Fig. 3.

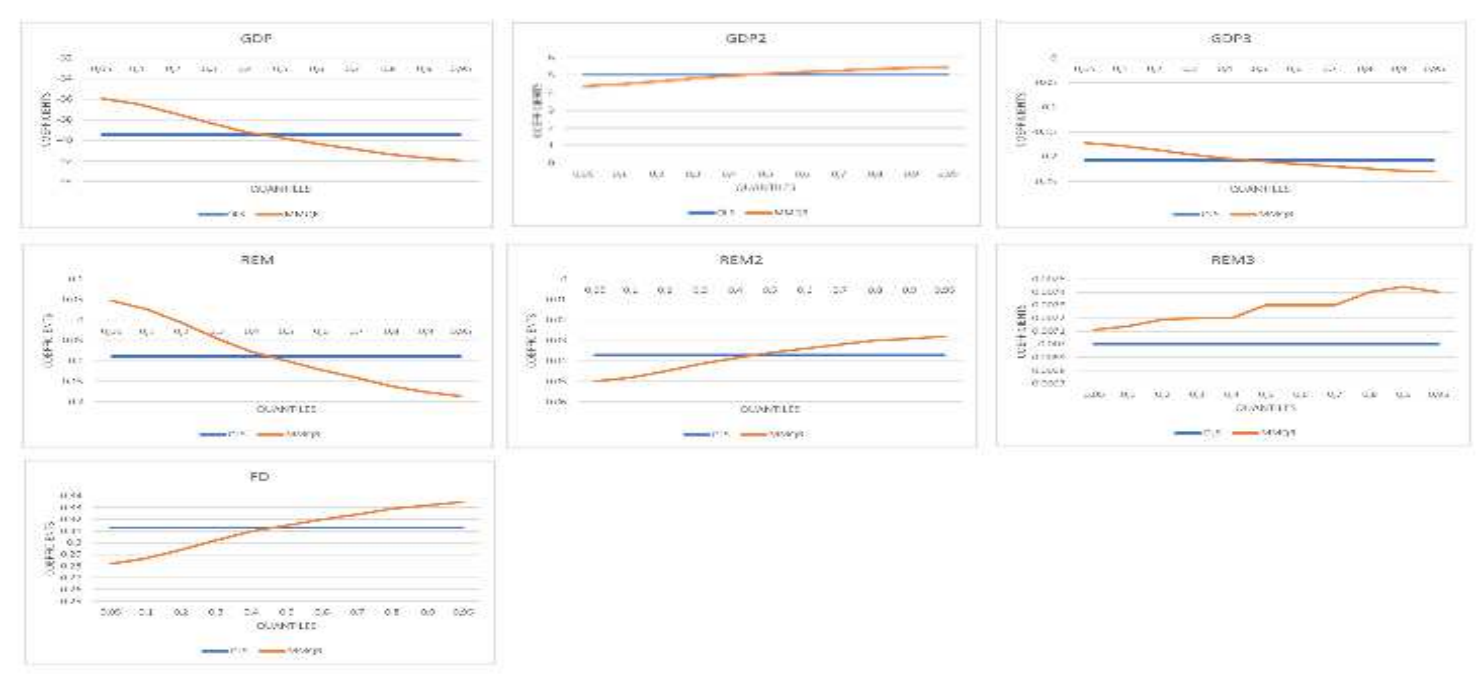

Fig3: Graphics of estimated coefficients from OLS and MMQR across all quantiles for all variables in UMIC

\section{5- Conclusion and Policy implications}

The main purpose of this study is to investigate whether remittances inflow could affect the environment in developing countries. Examining the relationship between remittances and environment is for great importance given the magnitude of this external funding in the developing countries, and that policy makers in LDCs are increasingly concerned with environmental degradation.

In line with this feature, this study seeks to evaluate the validity of the environmental Nshaped Kuznets curve hypothesis for remittances along with the conventional EKC in LIC, LMIC and UMIC countries from 1980 to 2014. In this study, financial development is considered as control variable. 
We have adopted the recent method of moments quantile regression with fixed effect introduced by (Machado and Silva (2019)) to explore the effects of the considered variables on different quantiles of $\mathrm{CO}_{2}$ emissions.

The empirical results showed heterogeneous effects of remittances, income and financial development on $\mathrm{CO}_{2}$ emissions across different quantiles in each panel-country.

The panel quantile regression reveals interesting patterns about the effect of remittances on $\mathrm{CO}_{2}$ emissions. In particular, remittances begin to exert negatively significant effects on $\mathrm{CO}_{2}$ emissions mainly at higher quantiles in (LMIC) and from medium to higher quantiles in (UMIC). On the contrary, we do not find significant spillover from remittances to $\mathrm{CO}_{2}$ emissions in low quantiles meaning that in low $\mathrm{CO}_{2}$ emitters, remittances support households for their subsistence needs away from what could harm the environment.

The analysis of remittances coefficients and their second and third polynomial values support the validity of an inverted N-shaped Kuznets curve for remittances in LMIC at higher quantiles highlighting the importance of remittance as a contributor to the pollution decrease. Afterward, a U-shaped EKC is observed from $40^{\text {th }}$ to the 80th quantiles in (UMIC). However, given the values of Rem and $\mathrm{Rem}^{2}$, a monotonic negative effect of remittances on environment are found in UMIC at highest quantiles, excluding the existence of EKC. The negative monotonic effect on $\mathrm{CO}_{2}$ emissions in UMIC indicate that the quest to improve remittances inflows in these countries should enhance environmental quality. Nevertheless, the positive value of $\mathrm{Rem}^{3}$ in UMIC argues that the environmental gains resulting from remittances can be negatively affected if some measures of mitigation and awareness are not adopted to reduce pollution.

When considering the relationship between GDP per capita and $\mathrm{CO}_{2}$ emissions, our results support an inverted N-shaped Kuznets curve for income at all quantiles in UMIC and at both lower and middle quantiles $\left(5^{\text {th }}-60^{\text {th }}\right)$ in LIC. The empirical results found from LIC and UMIC are consistent with the idea that increasing production should not always causes environmental damages but in opposite could improve environmental quality. This consistent effect is occurred especially when improving energy efficiency and technological innovation.

As for financial development, this component exerts mixed effect on $\mathrm{CO}_{2}$ emissions across different panel with respect to the degree of financial markets development. We find a positive effect at all quantiles in both LMIC and UMIC. In LIC, financial development led to a negative aggregated effect on $\mathrm{CO}_{2}$ emissions from lower quantiles to the first middle quantile $\left(5^{\text {th }}-40^{\text {th }}\right)$. Another interesting result is that remittances reveal a substitute funding tool to the financial development especially when dealing with underdeveloped financial markets.

To conclude, our findings have several implications and provide useful insights to policymakers. First, reliance only on mean regression results may induce ineffective policy implications. Second, policies need to be established individually for each country depending on their specificities in terms of remittances, incomes and financial system. Thirdly, it is inferred that, beyond the role played in terms of economic and financial development and in terms of funding support for households, the remittances are a powerful tool allowing affecting the environment depending on how they are allocated. Hence, it is at first imperative to avoid structural inefficiencies and bureaucracy issues in order to facilitate received remittances and to be formally sent. Besides, reducing remittances costs and considering incentives to increase remittance inflows to the country remains a suitable target under sustainable development. Fourth, there is evidence to implement effective financial system to soften investment credits 
granting intended for clean technology and for projects funding which are complying with the environment. Meanwhile, promote research and development for cleaner production remains a suitable action to ensure sustainable environment.

For further researches, it should be argued that the relationships between environment and the considered variables are more complex and should be taken with great carefulness. Incorporate other control variables, classify the countries according to other criteria as well as the availability of large dataset are also required to more accurately capture the different effects and may explicit the inconclusive results in various quantiles in our study.

1- Ethics approval and consent to participate: "Not applicable" in this section.

2- Consent to Publish: "Not applicable" for this paper.

3- Availability of data and materials: The datasets analyzed during the current study are available in the World Development Indicators in World bank Data.

4- Competing interests: "The authors declare that they have no competing interests" in this section.

5- Funding: There is no funding for this study.

\section{6- Authors Contributions}

\begin{tabular}{|l|l|}
\hline \multicolumn{1}{|c|}{ Authors } & \multicolumn{2}{c|}{ Contribution } \\
\hline Mahmoud el Batanony & Conceptualization \\
\hline Imed Attiaoui & $\begin{array}{l}\text { Methodology; Formal analysis and } \\
\text { investigation; Writing original draft } \\
\text { preparation }\end{array}$ \\
\hline Ibrahim Ali Ali & Software; Formal analysis and investigation \\
\hline Nahla Nasser & $\begin{array}{l}\text { Collection of the data; Writing, review and } \\
\text { editing }\end{array}$ \\
\hline Monaem Tarchoun & Writing; review and editing; Literature \\
\hline
\end{tabular}




\section{References}

Ahmad, M,Ul Haq Z, Khan Z et al (2019) Does the inflow of remittances cause environmental degradation? Empirical evidence from China. Econ Res Istrazivanja 32:2099 2121.

Allard, A., Takman, J., Uddin, GS,. Ahmed A (2018) The N-shaped environmental Kuznets curve: an empirical evaluation using a panel quantile regression approach. Environ Sci Pollut Res 25:5848-5861

Alvarez, H. A, Balsalobre, L.D. (2016) Economic growth and energy regulation in the environmental Kuznets curve. Environ Sci Pollut Res 23(16):16478-16494

Apergis, N., Cooray,A. (2018). Asymmetric real exchange rates and poverty: The role of remittances. Emerging Markets Review.

Ayeche, M. B., Barhoumi, M., \& Amin, M. (2016). Causal linkage between economic growth, financial development, trade openness and $\mathrm{CO} 2$ emissions in European Countries. American Journal of Environmental Engineering, 6, 110-122.

Azizi, S. (2018).The impacts of workers' remittances on human capital and labor supply in developing countries. Economic Modelling: 1-20

Bang, J. T., Mitra, A., and Wunnava, P. V. (2016). Do remittances improve income inequality? An instrumental variable quantile analysis of the Kenyan case. Economic Modelling, 58:394 - 402.

Bekhet, H. A., Othman, N. S. (2017). Impact of urbanization growth on Malaysia CO2 emissions: Evidence from the dynamic relationship. Journal of cleaner production, 154, 374- 388.

Benhamou, A.Z.,Cassin, (2020). The impact of remittances on savings, capital and economic growth in small emerging countries. Economic Modelling.

Bhattarai K, Paudel KP, Poudel BN (2009) Searching for an environmental Kuznets curve in carbon dioxide pollutant in Latin American countries. J Agric Appl Econ 41(1):13-27

Boufateh, T. (2019) The environmental Kuznets curve by considering asymmetric oil price shocks: evidence from the top two. Environ Sci Pollut Res 26(1):706-720.

Boufatah, T., Saadaoui, Z. (2020). Do Asymmetric Financial Development Shocks Matter for $\mathrm{CO}_{2}$ Emissions in Africa? A Nonlinear Panel ARDL-PMG Approach. Environmental Modeling an Assessment.

Bouoiyour, J., Miftah, A., 2016. Education, male gender preference and migrants' remittances: interactions in rural Morocco. Econ. Modell. 57, 324-331.

Brown, R. P. C., Carmignani, F., and Fayad, G. (2013). Migrants' Remittances and Financial Development: Macro- and Micro-Level Evidence of a Perverse Relationship. The World Economy, 36(5):636-660.

Canay I,A., (2011) A simple approach to quantile regression for panel data. Econ J 14:368386

Chami, R., Fullenkamp, C., Jahjah, S. (2005), Are immigrant remittance flows a source of capital for development?. IMF Staff papers, 52(1), 55-81 
Charfeddine, L., Kahia, M., 2019. Impact of renewable energy consumption and financial development on CO 2 emissions and economic growth in the MENA region: A panel vector autoregressive (PVAR) analysis. Renew. Energy 139, 198-213.

Clemens, M. A. and McKenzie, D. (2018). Why don't remittances appear to affect growth? The Economic Journal, 128(612):F179-F209.

Coulibaly, D. (2015). Remittances and financial development in Sub-Saharan African countries: A system approach. Economic Modelling, 45:249 - 258.

Farhani, S., \& Ozturk, I. (2015). Causal relationship between CO2 emissions, real GDP, energy consumption, financial development, trade openness, and urbanization in Tunisia. Environmental Science and Pollution Research, 22(20), 15663.

Fromentin, V. (2017). The long-run and short-run impacts of remittances on financial development in developing countries. The Quarterly Review of Economics and Finance, 66:192 - 201.

Giuliano, P. and Ruiz-Arranz, M. (2009). Remittances, financial development, and growth. Journal of Development Economics, 90(1):144 - 152.

Goschin, Zizi. (2014). "Remittances as an Economic Development Factor. Empirical Evidence from the CEE Countries." Procedia Economics and Finance.

Grossman, G.M., Krueger, A.B.(1995). Economic growth and the environment. Q. J. Econ. 110 (2), 353-377.

Gunasekaran, A., Jabbour, C. J. C., Jabbour, A. B. L. D. S. (2014). Managing organizations for sustainable development in emerging countries: an introduction. International Journal of Sustainable Development \& World Ecology, 21(3), 195-197.

Ito, K. (2017). CO2 emissions, renewable and non-renewable energy consumption, and economic growth: Evidence from panel data for developing countries. International Economics, 151, 1-6.

Jebli, M. B., Youssef, S. B., Ozturk, I. (2016). Testing environmental Kuznets curve hypothesis: The role of renewable and non-renewable energy consumption and trade in OECD countries. Ecological Indicators, 60, 824-831

Jouini, J., 2015. Economic growth and remittances in Tunisia: bi-directional causal links. A.C. Marques et al. Energy Policy 116 (2018) 257-265 264 J. Policy Model. 37, 355-373

Kadozi, E. (2019). Remittance Inflows and Economic Growth in Rwanda.Research In Globalisation

Kayani, G.M., Ashfaq, S., Siddique, A. (2020). Assessment of Financial Development on Environmental Effect: Implications for Sustainable Development. Journal of Cleaner Production, Volume 261.

Khan, Z. U., Ahmad, M., Khan, A. (2020). On the remittances-environment led hypothesis: Empirical evidence from BRICS economies. Environmental Science and Pollution Research. 27, pages 16460-16471.

Koenker, R. (2004). Quantile regression for longitudinal data. Journal of Multivariate Analysis, 91(1), 74-89.

Koenker, R., Bassett, G. (1978). Regression Quantiles. Econometrica, 46(1), 33-50. doi: $10.2307 / 1913643$ 
Koska, O.A., Saygin, P.Ö., Çağatay, S., Artal-Tur, A., 2013. International migration, remittances, and the human capital formation of Egyptian children. Int. Rev. Econ. Finance 28, 38-50.

Li, S., Zhang, J., \& Ma, Y. (2015). Financial development, environmental quality and economic growth. Sustainability, 7(7), 9395-9416.

Machado, J.A., Silva, J.S., 2019. Quantiles via moments. Journal of Econometrics.

Mamun, M. A., Sohag, K., Uddin, G. S., and Shahbaz, M. (2015). Remittance and domestic labor productivity: Evidence from remittance recipient countries. Economic Modelling, 47:207 - 218.

McKenzie, D., \& Sasin, M. (2007). Migration, remittances, poverty, and human capital: Conceptual and empirical changes. World Bank policy research working paper 4272.

Meyer, Dietmar, and Adela Shera. 2016. "The Impact of Remittances on Economic Growth: An Econometric Model.” EconomiA 18 (2). National Association of Postgraduate Centers in Economics, ANPEC: 147-55.

Nasir, M.A., Huynh, T.L.D., Tram, H.T.X., (2019). Role of financial development, economic growth \& 771 foreign direct investment in driving climate change: A case of emerging ASEAN. J. Environ. Manage. 772 242,131-141.

Nyamongo, E. M., Misati, R. N., Kipyegon, L., and Ndirangu, L. (2012). Remittances, financial development and economic growth in Africa. Journal of Economics and Business, 64(3):240 - 260.

Opperman, P. and Adjasi, C. K. D. (2019). Remittance volatility and financial sector development in sub-Saharan African countries. Journal of Policy Modeling, 41(2):336 - 351 .

Pata, U. K. (2018). Renewable energy consumption, urbanization, financial development, income and $\mathrm{CO} 2$ emissions in Turkey: testing EKC hypothesis with structural breaks. Journal of Cleaner Production, 187, 770-779.

Pilarova, T, Kandakov A (2017). The impact of remittances on school attendance: the evidence from the Republic of Moldova. Int J Educ Dev 55:11-6

Rahman Z, Hongbo C, AhmadM(2019a) A new look at the remittances-FDI-energyenvironment nexus in the case of selected Asian nations Singapore Econ Rev

Salas, V. B. (2014). International Remittances and Human Capital Formation. World Development, 59:224 - 237.

Sapkota P, Bastola U (2017) Foreign direct investment, income, and environmental pollution in developing countries: panel data analysis of Latin America. Energy Econ 64:206212.

Sarkodie, S. A., Strezov, V. (2019a). A review on environmental Kuznets curve hypothesis using bibliometric and meta -analysis. Science of the total environment, 649, 128 145.

Sarkodie SA, Strezov V (2019b) Effect of foreign direct investments, economic development and energy consumption on greenhouse gas emissions in developing countries. Sci Total Environ 646:862-871.

Senbeta, A. (2013). Remittances and the sources of growth. Applied EconomicsLetters, 20, $572-580$. 
Shah, D. (2017). Role of Remittances. Opinion, The Himalayan. Retrieved from https://thehimalayantimes.com/opinion/role-of-remittances/.

Shahzad, S. J. H., Kumar, R. R., Zakaria, M., Hurr, M. (2017). Carbon emission, energy consumption, trade openness and financial development in Pakistan: A revisit. Renewable and Sustainable Energy Reviews, 70, 185-192.

Sharma, K., Bhattarai, B., \& Ahmed, S. (2019). Aid, growth, remittances and carbon emissions in Nepal. Energy Journal, 40(1), 129-141.

Sobiech, I. (2019). Remittances, finance and growth: Does financial development foster the impact of remittances on economic growth? World Development, 113:44 - 59.

Thapa, S., and Acharya, S. (2017). "Remittances and Household Expenditure in Nepal: Evidence from Cross-Section Data." Economies 5(16): 1-17.

Vacaflores, D.E. (2018). Are Remittances helping lower Poverty and Inequality levels in Latin America? The Quarterly Review of Economics and Finance.

Wangle UR, Devkota S (2018) The impact of foreign remittance e on poverty in Nepal: a panel study of household survey data 1996-2011. World Dev 110:38-50

Wang, Y., Zhang, Q., Li, C. (2019). The contribution of non-fossil power generation to reduction of electricity-related $\mathrm{CO} 2$ emissions: A panel quantile regression analysis. Journal of Cleaner Production, 207, 531-541.

World Bank Group. (2018). Migration and remittances: Recent development and outlook. Washington: World Bank Group.

World Bank (2020) World development indicators (WDI) |

Xing, T., Jiang, Q., Ma, X. (2017). To facilitate or curb? The role of financial development in China's carbon emissions reduction process: A novel approach. International Journal of Environmental Research and Public Health, 14(10), 1222.

Ziesemer, T.H., 2012. Worker remittances, migration, accumulation and growth in poor developing countries: survey and analysis of direct and indirect effects. Econ. Modell. 29 (2), 103-118.

Zhu, H., Li, Z., Guo, P. (2018). The impact of income, economic openness and interest rates on housing prices in China: evidence from dynamic panel quantile regression. Applied Economics, 50(38), 4086-4098. 
Figures
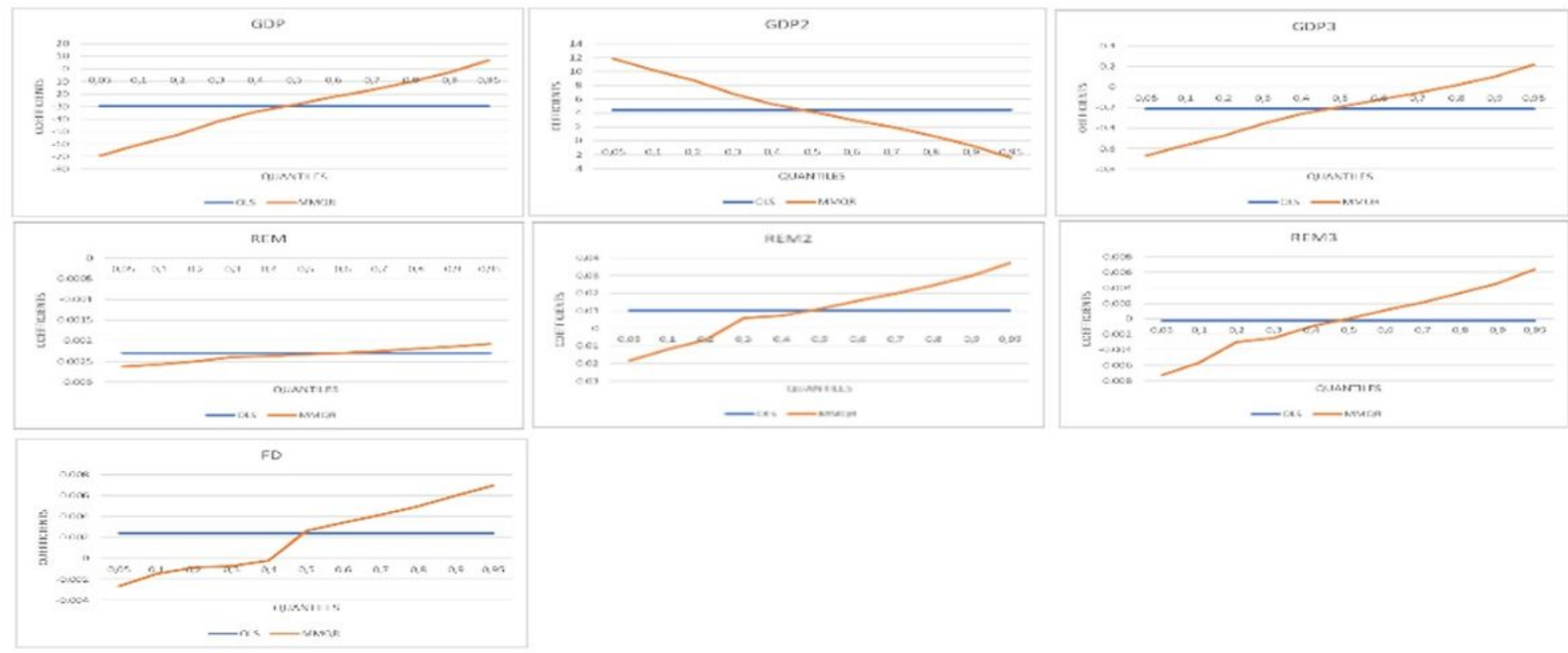

\section{Figure 1}

Graphics of estimated coefficients from OLS and MMQR across all quantiles for all variables in LIC
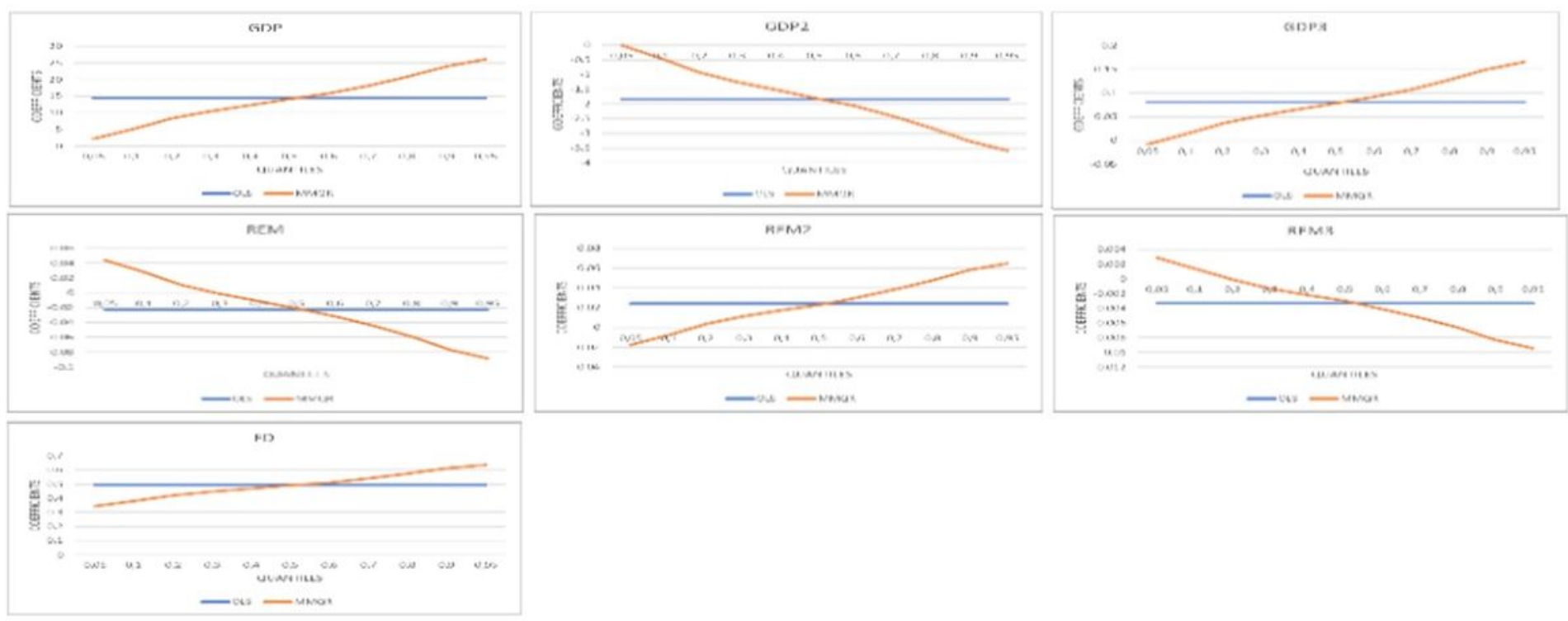

\section{Figure 2}

Graphics of estimated coefficients from OLS and MMQR across all quantiles for all variables in LMIC 